\title{
Prevalence and control of cardiovascular risk factors in Poland. Assumptions and objectives of the NATPOL 2011 Survey*
}

\author{
Tomasz Zdrojewski ${ }^{1}$, Marcin Rutkowski ${ }^{1}$, Piotr Bandosz ${ }^{1}$, Zbigniew Gaciong ${ }^{2}$, Tadeusz Jędrzejczyk ${ }^{3}$, \\ Bogdan Solnica ${ }^{4}$, Michał Pencina ${ }^{5}$, Wojciech Drygas ${ }^{6,7}$, Bogdan Wojtyniak ${ }^{8}$, Tomasz Grodzicki ${ }^{9}$, \\ Jerzy Piwoński ${ }^{6}$, Bogdan Wyrzykowski ${ }^{1}$
}

\author{
1Department of Hypertension and Diabetology, Medical University of Gdansk, Poland \\ 2Department of Internal Medicine, Hypertension and Vascular Disease, Medical University of Warsaw, Poland \\ ${ }^{3}$ Department of Public Health and Social Medicine, Medical University of Gdansk, Poland \\ ${ }^{4}$ Department of Diagnostics Chair of Clinical Biochemistry, Jagiellonian University Medical College, Krakow, Poland \\ ${ }^{5}$ Department of Biostatistics, Boston University, Boston, USA \\ ${ }^{6}$ Department of Epidemiology, CVD and Health Promotion, National Institute of Cardiology, Warsaw, Poland \\ ${ }^{7}$ Department of Social and Preventive Medicine, Medical University, Lodz, Poland \\ ${ }^{8}$ National Institute of Public Health — National Institute of Hygiene, Warsaw, Poland \\ ${ }^{9}$ Department of Internal Medicine and Gerontology, Jagiellonian University Medical College, Krakow, Poland
}

*Acronym of the survey NATPOL: PL: Nadciśnienie tętnicze oraz inne czynniki ryzyka chorób serca i naczyń w Polsce (Arterial hypertension and other CVD risk factors in Poland)

\begin{abstract}
A bstract
Background: Cardiovascular diseases (CVD) have been the main cause of death in Poland for the last five decades. In 2010, CVD caused $46.0 \%$ of all deaths in Poland. An analysis performed using the IMPACT model, have shown that the reduction in mortality due to ischaemic heart disease, which took place in Poland, was primarily a result of lifestyle changes and of changes affecting risk factors in the population of adults. From the perspective of health policy planning it is very important to know the prevalence of CVD risk factors and to be aware of trends in the population.

Aim: The NATPOL 2011 Survey was a cross-sectional observational study aimed to assess the prevalence and control of CVD risk factors in Poland. The aim of this paper is to describe the objectives and methodology of the NATPOL 2011 project.

Methods: The survey was designed as a representative observational study and was carried out on a representative sample of Polish residents aged 18-79 years. The planned size of the research sample was 2,400 subjects. Participants were randomly selected in bundles, in a stratified, proportional draw performed in three stages. The study was composed of a questionnaire interview, blood pressure and anthropometric measurements as well as a blood and urine sample collection. The examination consisted of two visits at subjects' homes and was performed by well-trained nurses.

Results and conclusions: Letters of invitation were sent to 4,420 potential participants. Of those, 786 persons could not be contacted because the addresses were wrong, the respondents resided at an address other than their registered place of residence or, in some cases, the respondents died prior to the survey. Among 3,634 addresses of the persons sampled for the study there were 661 (M: 328, F: 333) "closed doors" (the nurse was unable to contact the respondent during three consecutive attempts) and 560 (M: 295, F: 265) direct refusals. Finally, 2,413 subjects participated in the study and 2,401 of them completed all the procedures in the survey. The data mentioned above give the response rate of $66.4 \%$. The structure of the study sample, including age groups and gender is almost identical to the structure of the adult population of Poland in 2010, according to the Central Statistical Office data. The sample reflected the structure of the adult population quite well, therefore the weights' adjustments calculated for epidemiological analyses were in range from 0.36 to 4.11 .
\end{abstract}

Key words: cardiovascular diseases, risk factors, prevalence

Kardiol Pol 2013; 71, 4: 381-392

\section{Address for correspondence:}

Ass. Prof. Tomasz Zdrojewski, Department of Hypertension and Diabetology, Medical University of Gdansk, ul. Dębinki 7, 80-211 Gdańsk, Poland,

tel/fax: +48 5834925 38, e-mail: tz@gumed.edu.pl

Received: 06.03.2013 Accepted: 19.03.2013

Copyright (c) Polskie Towarzystwo Kardiologiczne 


\section{INTRODUCTION}

Cardiovascular diseases (CVD) have been the main cause of death in Poland for the last five decades. In 2010, CVD caused $46.0 \%$ of all deaths in Poland $(40.8 \%$ in males [M], and $51.8 \%$ in females [F]) [1]. CVD are also the leading cause of premature mortality - in 2010 they were responsible for $26.9 \%$ of all deaths in people aged below 65 years [1]. Almost a quarter $(23.8 \%$ ) of all disability cases (occurring for the first time in life), where the subject is unable to continue their professional activity and stay in a job, can be attributed to CVD [2]. These facts constitute a substantial medical, social and economic burden.

Since 1991, cardiovascular mortality in Poland has been steadily decreasing [3]. Several Central-Eastern European [CEE] countries which experienced equally dramatic political changes and socioeconomic transformation in the early 1990s, including the Czech Republic, Hungary, and Romania, have presented similar trends [4]. However, despite these changes, CVD mortality rates in Poland and other CEE countries after transformation still remain much higher than the EU average [4].

Residents of Poland live 3-7 years less than citizens of the 'old' EU countries. The decisive factor contributing to this outcome is the fact that CVD-related mortality rates among Polish men and women are higher than those in the majority of other countries of the European Union (Fig. 1A, B) [5, 6].

An analysis performed using the epidemiological IMPACT model, and data from cross-sectional surveys conducted between 1991 and 2005, have shown that the reduction in mortality due to ischaemic heart disease which took place over that period was primarily the result of lifestyle changes and of changes affecting risk factors in the population of adults in Poland (54\% of the observed reduction in mortality) [7]. Developments in the field of restorative medicine (specifically cardiac treatments) also significantly contributed to reducing the number of deaths, but to a smaller extent (37\%) [7].

Hence, it is essential that government health policy planners monitor the prevalence of lifestyle-dependent CVD risk factors. Even more importantly, they should be aware of trends regarding the prevalence of CVD risk factors in the population. This would allow them to anticipate future changes in mortality, and evaluate the benefits of various population-based prevention strategies concerning CVD, targeting high-risk factors and groups.

The most recent large-scale cross-sectional studies of prevalence and control of CVD risk factors in the general adult population in Poland were carried out in 2002 (NATPOL 2002) [8, 9] and between 2004 and 2007 (WOBASZ) [10]. It has been established that the intervals between surveys should not be excessively long, since it has been shown that, after effective population-scale interventions, changes may occur much faster than had been believed until now (i.e. even after a period as short as several months [11]). Thus, it was imperative to schedule a new study to be carried out in 2011.
The NATPOL 2011 Survey sought to describe the prevalence and control of CVD risk factors in a representative sample of adults. The aim of this paper is to describe the objectives of the NATPOL project, as well as the recruitment procedure and the characteristics of the study group, the methodology of research and the study flow.

\section{Research objectives and main survey characteristics}

The NATPOL 2011 Survey was a cross-sectional observational study aimed to assess the prevalence and control of CVD risk factors in Poland, based on a representative sample of adults aged 18-79. The survey was carried out between January and August 2011. The main aim of the survey was to assess the prevalence and control of arterial hypertension, sedentary lifestyle, smoking, lipid disorders, metabolic syndrome, obesity and diabetes, as well as other factors related to CVD risk such as chronic kidney disease, sleeping disorders, depression and selected psychosocial factors. We also wanted to determine changes in those risk factors in the adult population in Poland between the 2002 (the NATPOL 2002 Survey) [8, 9] and 2011 (the NATPOL 2011 Survey).

The study was composed of a questionnaire, blood pressure (BP) and anthropometric measurements as well as a blood and urine sample collection. The examination consisted of two visits to subjects' homes and was performed by trained nurses. The questionnaire was completed during the first visit, while the Beck Depression Inventory was given to the subject to be self-completed, and was collected at the second visit. BP readings were taken three times during the first and the second visit. Blood and urine samples were taken from subjects at the second visit, after 10 to 12-hour fasting.

\section{Institutional partners and scientific board}

The fieldwork was subcontracted to a company specialising in market research projects for the private and public sectors. The transportation of biological material to the Central Laboratory was subcontracted to a firm with expertise in blood sample transport over long distances. Interviewers were recruited from among professionally active nurses. Most of them were social nurses working within local communities. All nurses participating in the survey completed special training prepared for fieldwork executors of the NATPOL 2011 Survey.

The key parties responsible for project design and protocol were experts from the Department of Arterial Hypertension and Diabetology of the Medical University in Gdansk and, for the implementation and execution, a team from the University Clinical Centre of the Medical University in Gdansk. The main institutional partners that co-operated in preparing the protocol and implementation of the project were: Department of Internal Diseases, Hypertension and Angiology, Medical University of Warsaw, Medical College of the JagielIonian University in Krakow, Department of Epidemiology, 


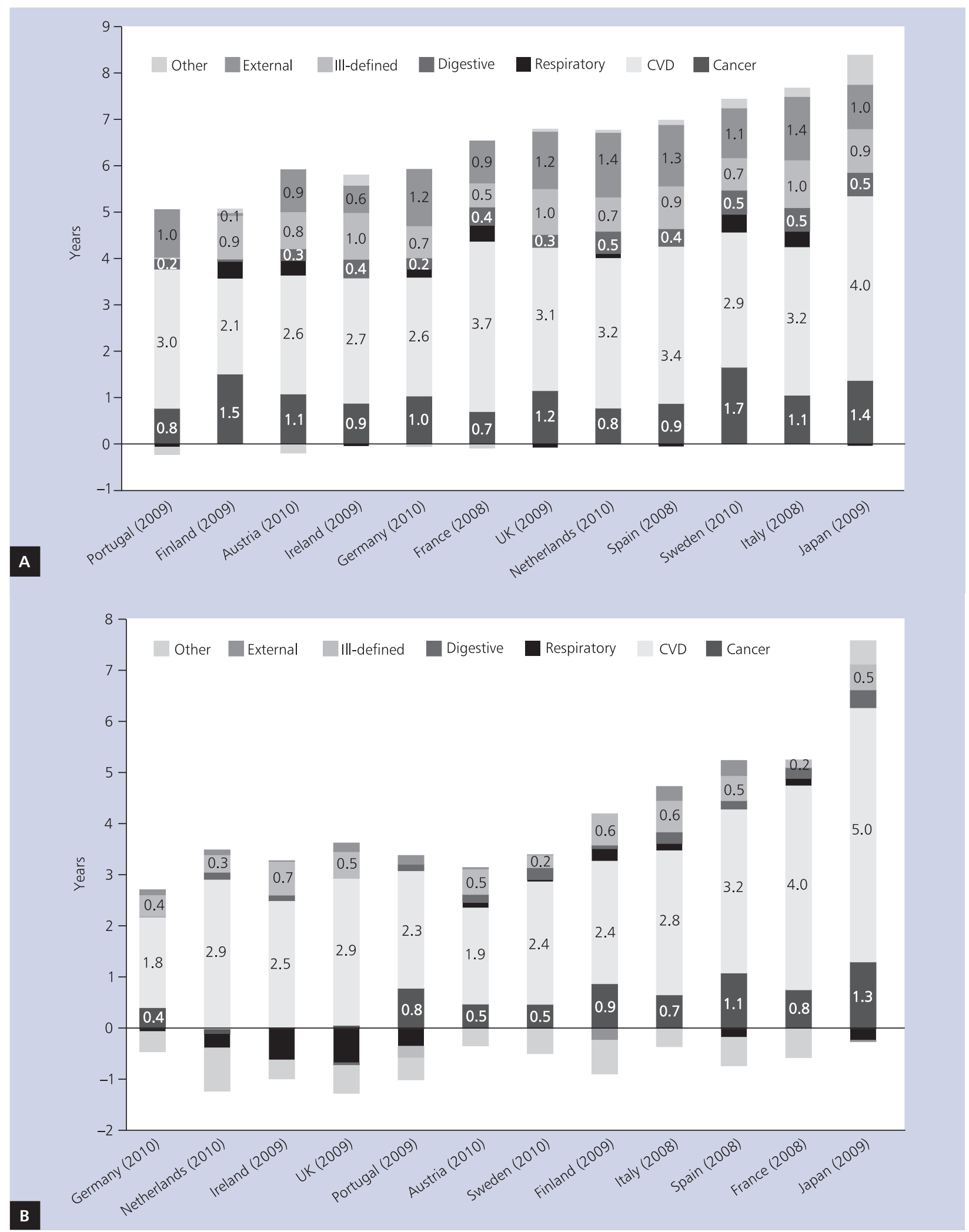

Figure 1. A. Contribution (number of years) of higher mortality to main causes of death among Polish men in shortening their life expectancy compared to men in some other countries, 2010 or latest available year [5]; B. Contribution (number of years) of higher mortality to main causes of death among Polish women in shortening their life expectancy compared to women in some other countries, 2010 or latest available year [5]; CVD — cardiovascular diseases 
Cardiovascular Disease Prevention and Health Promotion of the Institute of Cardiology in Warsaw, Centre of Monitoring and Analyses of Population Health of the National Institute of Public Health - National Institute of Hygiene in Warsaw, and School of Public Health, Statistics and Consulting Unit at Boston University.

The Scientific Board developed the study protocol and the application to the Ethical Committee, elaborated survey questionnaires, selected blood and urine tests, and established and approved laboratory methods, prepared instructions for nurse trainers, monitored the study flow, controlled the work of the Central Laboratory, and the preparation of the central database.

\section{METHODS}

\section{Recruitment of subjects and the research sample}

The survey was designed as a representative observational study and was carried out on a representative sample of Polish residents aged 18-79 years. The planned size of the research sample was 2,400 subjects. Research participants were randomly recruited in bundles, in a stratified, proportional draw performed in three stages. The first stage draw identified local administrative units: urban, rural and urban-rural municipalities. Figure 2 shows the distribution of $248 \mathrm{mu}-$ nicipalities randomly drawn in the NATPOL 2011 Survey. During the second stage, streets in urban municipalities and villages in rural municipalities were drawn. The third stage of the draw enabled the random identification of individuals in bundles and was executed using the national PESEL database (Polish Universal Electronic System for Registration of the Population) maintained by the Ministry of Internal Affairs and Administration.

The first stage draw identified local administrative units, including urban, rural, and urban-rural municipalities (gmina). It was a stratified proportional draw. Geographical strata were created on the basis of 16 provinces (województwo) within which there were four location type classes (16 provinces times four location type class, minus exceptions $=61)$. Location type classes were defined as follows: village/countryside; town with population up to 50,000; town/city with population from 50,001 to 200,000; city with population over 200,000.

The number of residents aged 18 years and over was determined for each stratum. The number of interviews to be conducted in each stratum was determined so as to ensure that it was proportional to the number of adult residents in the relevant stratum and that the total interview count was kept at 2,400. The number of geographical bundles drawn was determined to be $\mathrm{w}=$ round $(\mathrm{n} / \mathrm{s})=218$, where $\mathrm{n}$ means the planned total number of interviews and $s$ the average number of interviews in a bundle (11). The sampling interval was calculated by dividing the size of the population aged 18 to $79(29,605,773)$ by the number of bundles and rounding the result to the nearest integer. The resulting number

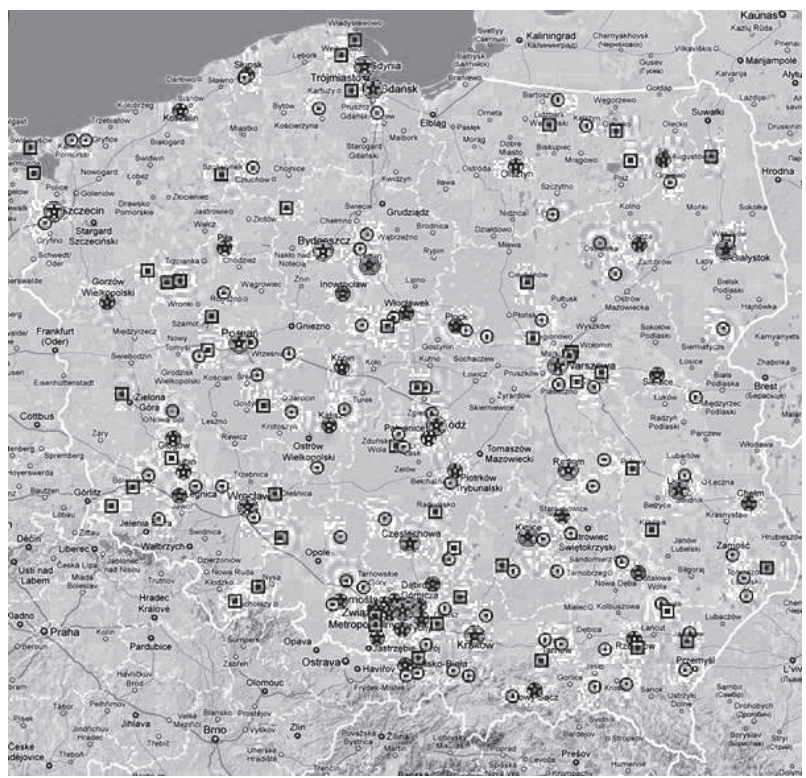

Figure 2. Distribution of municipalities (gmina) randomly drawn in the NATPOL 2011 Survey; Legend: Village; id Town $\leq 50,000$ reidents (age $0+$ ); Town 50,001-200,000 residents (age $0+$ ); City $>200,000$ residents (age $0+$ )

was I $=135,806$. All the municipalities where population size exceeds the value of I (in total: 22 urban municipalities) were automatically included in the sample. The number of interviews in these municipalities was determined proportionally to the number of adult residents of these municipalities relative to the number of all adult residents of Poland. The remaining municipalities were sorted according to province, location type class and a pseudorandom variable with a uniform distribution. The RAND ('UNIFORM') function of the SAS software was used. The number of interviews for each stratum was set to be proportional to the size of the population in the stratum. The sampling interval was separately determined for each stratum, in a way similar to the method described above. The municipalities to be included in the sample were selected according to the interval thus derived. The number of interviews in each municipality was determined so as to obtain within the stratum a similar number of interviews per municipality, and to obtain the sum total for the stratum equal to the number of interviews to be completed in that stratum. The number of respondents obtained in each stratum was proportional to the number of adult residents in the stratum.

The second stage of sample selection involved a random draw of bundles in municipalities i.e. streets in urban municipalities and villages in rural municipalities. In cases of mixed urban-rural municipalities, streets and villages were drawn, respectively. These bundles were drawn within the municipalities selected during the first phase of the sampling process. The sampling frame for the third stage of sample selection was the list of individuals aged 18-79 who live in the 
selected bundles, registered in the PESEL database. Separately in each geographical stratum, individuals were drawn in the numbers proportional to the number of residents in each one of the 12 demographic categories. These categories were defined on the basis of gender and age (i.e. male/female; six age categories: 18-24, 25-34, 35-44, 45-54, 55-64 and 65-79).

Because of the expected response rate, it was planned to draw a sample five times as large as the actual number of interviews planned. The sample thus drawn was divided into the base set of 2,400 addresses and supplementary sets. Supplementary address sets were used only when all the addresses in the base set were used up without reaching the target quantity of interviews (e.g. in the event of refusals or if contact with the respondent at the base address was not possible).

Description of an individual subject's examination The examination of an individual subject comprised the following components: (1) Completing the questionnaire; (2) Taking BP readings and anthropometric measurements; (3) Collecting blood and urine samples.

The survey fieldwork was carried out by 234 nurses who lived in or close to the randomly selected geographical bundles. The nurses were recruited and specifically trained for the study by the authors of the project. Prior to fieldwork, letters were sent to all the individuals selected in the random sampling procedure, providing information on the activities planned under the project, the project objectives and the implementation procedure. The project involved two visits by a nurse to the subject's home.

During the first visit the nurse:

1. briefly presented to the subject the objectives of the programme,

2. confirmed the subject's personal data and obtained written consent concerning participation in the survey,

3. completed the questionnaire,

4. performed a series of BP measurements - three BP measurements on the right arm,

5. took anthropometric measurements,

6. arranged the date and time of the next visit with the subject, providing information that blood samples would have to be taken after 10-12 hours of fasting and leaving the subject a container for a urine sample,

7. instructed the subject how to complete the Beck Depression Inventory before the second visit.

During the second visit, the nurse:

1. performed a second series of BP measurements,

2. took samples of venous blood from the patient, making sure that the patient had not taken any food or liquids of any calorific value in the previous 10 to 12 hours,

3. transferred the sample of urine from the container to a vacuum transport tube,

4. filled out the referral form to the lab and transported the blood and urine samples to the local laboratory designated by the co-ordinator of the study, within up to two hours after blood collection,

5. examined the score of the depression questionnaire. In the cases of respondents who had suicidal thoughts (question D9) and had been tested to receive $\geq 17$ points, or had a severe set of depressive symptoms (received $>21$ points), the nurse had to forward this information promptly to the co-ordinator of the study who contacted the patient and his or her family doctor.

\section{Study questionnaire}

The questionnaire consisted of six introductory, administrative questions or items (demographic data), 64 closed questions, eight open questions, five questions concerning education, marital status and employment, as well as five items to be filled in with the results of BP and anthropometric measurements. The standardised Beck Depression Inventory consisted of 21 questions. The English version of the main questionnaire and the Beck Depression Inventory are available online at: http://natpol.eu/files/NATPOL2011_questionnaire_english_translation.pdf

The medical part of the questionnaire included detailed questions about present clinical symptoms and diseases, medications taken by the subject, awareness of CVD risk factors, past medical history including details of all hospitalisations and family medical history in first degree relatives. Moreover, questions were asked concerning smoking, leisure time and occupational physical activity, sleep-related problems and sleep apnoea.

A separate section of the interview was dedicated to the respondent's knowledge about methods of CVD prevention and complications due to poor control of risk factors; the sources of knowledge about health and disease and the intentional usage of any preventive methods.

The final part of the questionnaire included questions concerning education, marital and professional status, as well as economic status and barriers concerning access to medical services.

\section{Blood pressure and anthropometric measurements} During the visits to the subject's home, the nurse took a series of BP readings (three during each visit). Each measurement was performed with the participant in a seated position, on the right upper arm, after at least $5 \mathrm{~min}$ of rest and at $1 \mathrm{~min}$ intervals. The patient was not allowed to smoke cigarettes, drink coffee or do physical exercise in the $30 \mathrm{~min}$ before the BP readings. The results were recorded in the medical questionnaire and on a special form given by the nurse to the subject at the conclusion of the visit with an interpretation of the results obtained. During the second visit, the BP measurements were performed before collecting the blood samples. BP readings were taken using fully automatic oscillometric BP measuring devices (A\&D UA 767), certified by the 


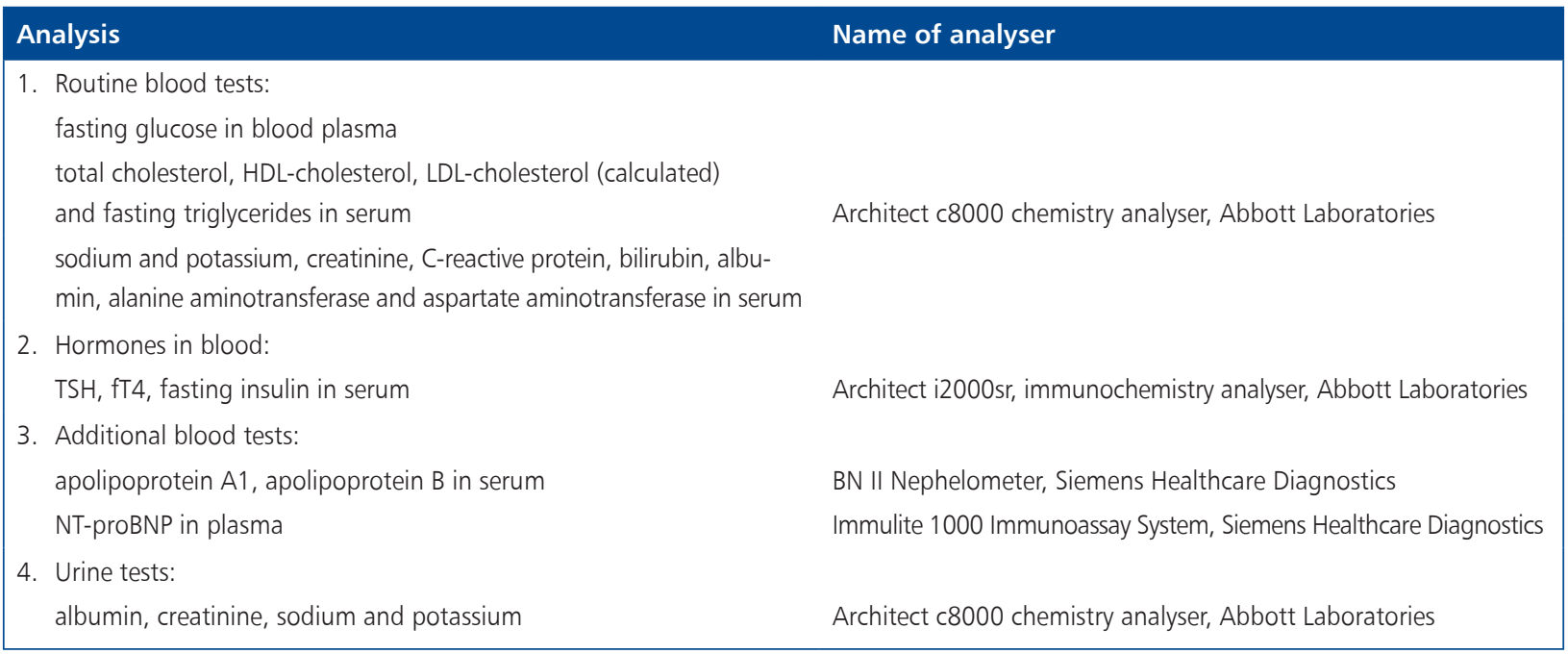

Association for the Advancement of Medical Instrumentation [12], the British Hypertension Society and the European Society of Hypertension [13]. Before the first measurement, the nurse measured the circumference of the patient's right arm. If the patient's arm circumference was $\geq 32 \mathrm{~cm}$, the readings were performed using a wider cuff. The nurse recorded the pulse rate and BP values with an accuracy of $1 \mathrm{~mm} \mathrm{Hg}$.

Anthropometric measurements included:

— weight - weighing the patient with his/her shoes off and dressed in light clothes (without outer garments - jackets, coats, etc.), using approved personal electronic scales, with accuracy to the nearest $0.1 \mathrm{~kg}$,

- height — using a portable personal measuring device, with accuracy to the nearest centimetre,

- waist, hip, and neck circumference - using a tailor's tape measure, with an accuracy to the nearest $0.5 \mathrm{~cm}$.

\section{Collecting blood and urine samples}

Blood samples were collected at the patient's home. The biological material was taken from the subject 10 to 12 hours after the last intake of food or fluid of any calorific value. The nurses visited the patient with a pre-assembled sampling kit.

Venous blood sample of $28 \mathrm{~mL}$ was collected from respondents in a sitting position using a vacuum tube system. After taking a sample of venous blood and transferring urine into a vacuum transport tube, the nurse transferred the samples to a local laboratory to obtain serum/plasma samples within up to two hours after blood collection.

Local laboratories were used in the study because they were located close to the geographical municipalities/bundles selected for the project. The task of the local laboratories was to perform the preliminary processing of biological material and to ensure its secure preservation i.e. to separate serum/plasma samples by centrifugation, to freeze the obtained plasma, serum and urine samples at $-20^{\circ} \mathrm{C}$ and to store them at $-20^{\circ} \mathrm{C}$ before transferring them to the Central Laboratory in Gdansk. Then the local laboratory prepared and released the material for transport to the Central Laboratory.

\section{Transport of the frozen material and testing in the Central Laboratory}

Within no more than six weeks, the biological material was transported to the Central Laboratory (Central Clinical Laboratory of the University Clinical Centre of the Medical University in Gdansk), where the blood and urine analyses were performed. The biological material was transported frozen, in containers with dry ice, by a courier company specialising in the transportation of blood samples.

After transporting the material to the Central Laboratory, one tube of frozen serum, as well as the plasma and urine samples, were thawed to perform the laboratory tests. The list of blood and urine tests performed and methodology are presented in Table 1 and Supplement 1. The results of routine biochemical laboratory tests were sent back to the participants. In the case of out-of-reference values, a special commentary and a letter advising the subject to consult a primary care physician was attached. The subjects with fasting glucose of 100-125 mg/dL or $\geq 126 \mathrm{mg} / \mathrm{dL}$ were additionally referred for a fasting plasma glucose test in a local laboratory.

\section{Ethical and legal issues}

The NATPOL 2011 Survey was approved by the Bioethics Commission of the Medical University in Gdansk. The approval concerned the questionnaire and all the procedures and measurements, including blood and urine tests and the storage of biological material for further scientific research. Before enrollment in the study, each participant signed an informed consent form. Each respondent was assigned a unique identification number to ensure confidentiality of personal data collected during the survey. All questionnaires and all 
blood and urine samples originating from a specific individual were coded with the same number. The data was coded and anonymously stored in the database. The personal data referenced in the database is protected against unauthorised access with a special password by the study co-ordinator for statistics and use of the database.

\section{Statistical issues}

The statistical analysis of the data was performed using SAS software for Windows (ver. 9.1.3) and R (The R Foundation). Basic statistical analyses involving estimation of the indicators defined in the study objectives were conducted using the procedures of SURVEYFREQ and SURVEYMEANS of the SAS package, taking into account the design effect of the survey.

\section{RESULTS}

\section{Flow of the study and response rate}

Letters of invitation were sent to 4,420 potential participants. Of those, we found in 786 cases that they were not eligible for the study because the participant's addresses were incorrect, or the respondents resided at an address other than their registered place of residence, or, in some cases, the selected respondents died prior to the survey.

Among 3,634 addresses and participants eligible for the study, there were 661 (M 328, F 333) 'closed doors' (the nurse was unable to contact the respondent during three consecutive attempts) and 560 (M 295, F 265) direct refusals.

Finally, 2,413 subjects participated in the study. 2,401 of the subjects completed all the procedures in the survey (i.e. the questionnaire interview, BP and anthropometric measurements, blood/urine sample taking), and the remaining

Table 2. Response rates in the NATPOL 2011 Survey

\begin{tabular}{|lccc|} 
& Males & Females & All \\
\hline In the whole study sample & $65 \%$ & $68 \%$ & $66.5 \%$ \\
According to place of residence: & & & \\
$\quad$ Village & $77 \%$ & $81 \%$ & $79 \%$ \\
Town $<50,000$ residents & $72 \%$ & $74 \%$ & $73 \%$ \\
Town 50,001-200,000 residents & $60 \%$ & $67 \%$ & $64 \%$ \\
City $>200,000$ residents & $46 \%$ & $53 \%$ & $50 \%$ \\
\hline
\end{tabular}

12 subjects completed all the procedures except for the blood/urine sample taking.

The data mentioned above gives a response rate of $66.5 \%$ (M: 65\%, F: 68\%) if all eligible respondents drawn from the PESEL registry are taken into consideration (Table 2). As expected, the response rate in villages and towns was higher than that obtained in cities.

\section{Characteristics of the study group}

Among the participants, there were 1,168 men and 1,245 women; 974 were aged 18-39, 849 - 40-59 years and $590-60-79$ years. The mean age in the examined sample was $44.9 \pm 16.0$ in men and $46.7 \pm 17.2$ in women. In 2011, the number of adults aged between 18 and 79 years in Poland was 29,733,134.

The structure of the study sample, including age groups and gender, is shown in Table 3. It was almost identical to the structure of the adult population of Poland in 2010, according to the Central Statistical Office (Table 3). The sample reflected the structure of the adult population quite well, therefore the weights' adjustments calculated for epidemiological analyses were from 0.36 to 4.11 . The socio-demographic characteristics of the study group are shown in Table 4.

\section{DISCUSSION \\ Research into CVD risk factors in Poland: historical background}

The first research into the epidemiology of arterial hypertension in Poland was carried out and published in 1929 in 'Polskie Archiwum Medycyny Wewnętrznej' by Prof. Januszkiewicz [14]. Viewed today, the analyses performed at the time were already very modern because they assessed the prevalence of hypertensive disease in relation to factors such as social class. In the 1950s, research into the epidemiology of arterial hypertension was carried out in Katowice and in Wroclaw by the teams of Prof. Tochowicz [15] and Prof. Falkiewicz [16], respectively. In the 1960s, cross-sectional research into the selected populations of adult residents of the towns of Plock and Sochaczew was carried out under the direction of Prof. Askanas [17, 18]. In 1983-1994, under the direction of Prof. Rywik and Prof. Sznajd, two research centres in Poland carried out research as part of the international multi-centre

Table 3. Structure of examined sample compared to structure of adult population in Poland in 2010 according to the Main Statistical Office in Poland [1]

\begin{tabular}{|c|c|c|c|c|c|c|}
\hline \multirow{2}{*}{$\begin{array}{l}\text { Age range: } \\
\text { 18-79 years }\end{array}$} & \multicolumn{2}{|c|}{ Males } & \multicolumn{2}{|c|}{ Females } & \multicolumn{2}{|c|}{ All } \\
\hline & NATPOL 2011 & Poland GUS* & NATPOL 2011 & Poland GUS* & NATPOL 2011 & Poland GUS* \\
\hline $18-39$ & $40.8 \%$ & $45.9 \%$ & $39.9 \%$ & $41.7 \%$ & $40.4 \%$ & $43.7 \%$ \\
\hline $40-59$ & $38.0 \%$ & $36.1 \%$ & $32.5 \%$ & $35.3 \%$ & $35.2 \%$ & $35.7 \%$ \\
\hline $60-79$ & $21.1 \%$ & $18.0 \%$ & $27.6 \%$ & $23.0 \%$ & $24.5 \%$ & $20.6 \%$ \\
\hline
\end{tabular}

* GUS - the Main Statistical Office in Poland - data from 2010 
Table 4. Socio-demographic characteristics of the study group

\begin{tabular}{|c|c|c|c|c|c|c|}
\hline \multirow[t]{2}{*}{ Characteristics } & \multicolumn{2}{|c|}{ Males } & \multicolumn{2}{|c|}{ Females } & \multicolumn{2}{|c|}{ All } \\
\hline & $\mathbf{N}$ & $\%$ & $\mathbf{N}$ & $\%$ & $\mathbf{N}$ & $\%$ \\
\hline \multicolumn{7}{|l|}{ Education } \\
\hline Primary or uncompleted primary & 124 & $10.6 \%$ & 139 & $11.2 \%$ & 263 & $10.9 \%$ \\
\hline Uncompleted secondary & 427 & $36.6 \%$ & 266 & $21.4 \%$ & 693 & $28.7 \%$ \\
\hline Secondary or uncompleted higher & 421 & $36.0 \%$ & 527 & $42.3 \%$ & 948 & $39.3 \%$ \\
\hline Higher & 196 & $16.8 \%$ & 313 & $25.1 \%$ & 509 & $21.1 \%$ \\
\hline \multicolumn{7}{|l|}{ Place of residence } \\
\hline Rural areas & 617 & $52.8 \%$ & 496 & $39.8 \%$ & 1113 & $46.1 \%$ \\
\hline Town $<50,000$ residents & 146 & $12.5 \%$ & 213 & $17.1 \%$ & 359 & $14.9 \%$ \\
\hline Town $50,000-200,000$ residents & 201 & $17.2 \%$ & 209 & $16.8 \%$ & 410 & $17.0 \%$ \\
\hline City $>200,000$ residents & 204 & $17.5 \%$ & 327 & $26.3 \%$ & 531 & $22.0 \%$ \\
\hline \multicolumn{7}{|l|}{ Professional status } \\
\hline Employed/economic activity & 660 & $56.7 \%$ & 589 & $47.4 \%$ & 1249 & $51.9 \%$ \\
\hline Farmer & 44 & $3.8 \%$ & 19 & $1.5 \%$ & 63 & $2.6 \%$ \\
\hline Pensioner & 272 & $23.4 \%$ & 407 & $32.8 \%$ & 679 & $28.2 \%$ \\
\hline Unemployed with unemployment pay & 18 & $1.5 \%$ & 11 & $0.9 \%$ & 29 & $1.2 \%$ \\
\hline Unemployed without unemployment pay & 64 & $5.5 \%$ & 80 & $6.4 \%$ & 144 & $6.0 \%$ \\
\hline Not working/student & 106 & $9.1 \%$ & 136 & $11.0 \%$ & 242 & $10.1 \%$ \\
\hline
\end{tabular}

WHO-MONICA Project (Monitoring Trends in Cardiovascular Diseases) which assessed the prevalence of risk factors and monitored trends with regard to changes [19].

Thus, as we can see, by the mid-1990s there had been valuable local or regional projects investigating risk factors in Poland, although insufficient to reflect the epidemiological situation on a national scale. In 1997, Zdrojewski et al. [20] assessed the prevalence of arterial hypertension in the NATPOL 1997 project, using for the first time a representative sample of 1,664 adult residents of Poland (aged 18-91). In the past decade, the main Polish research centres have carried out four new research projects on a nationwide scale, based on the representative method. The NATPOL PLUS (NATPOL 2002)project (Nadciśnienie Tętnicze w Polsce Plus Zaburzenia Lipidowe i Cukrzyca) was carried out in 2002 ( $n=3,051$, age range: 18-94) [8]. The WOBASZ project (Wieloośrodkowe Badanie Zdrowia Ludności) was carried out in 2003-2006 on a representative sample of 13,545 adult Poles aged 20-74 [10]. Another important research project which contributed to our knowledge of the epidemiology of arterial hypertension was the POLSENIOR study (Aspekty medyczne, psychologiczne, socjologiczne i ekonomiczne starzenia się ludzi w Polsce), carried out in 2007-2011 on a population of Polish residents aged over $64(n=4,949)$ [21].

\section{Sample selection procedure}

The NATPOL 2011 Survey used the representative sampling method. This method involves randomly selecting a subset of elements from the investigated population, so as to precisely reflect the structure of the general population. By measuring the attributes in the representative sample obtained in this way, researchers can draw conclusions concerning these attributes in the general population. Representative sampling allows researchers to draw conclusions only with regard to the population out of which the specific sample was randomly selected. Therefore, generalisations such as taking the conclusions from local research and extrapolating these to the national population are illegitimate and may lead to errors. This is particularly true with regard to CVD risk factors, since cardiovascular mortality rates differ significantly between various regions of Poland. Conducting research into CVD risk factors based on a national sample is much more difficult and expensive than carrying out research on a local or regional population. A specifically difficult aspect is presented by the requirement that biological material must be collected, pre-processed and transported from local centres to the central laboratory.

National samples used in the NATPOL series of research were each time obtained using the same multi-stage random sampling method. It is, therefore, possible to estimate the parameters for the whole population of Poland in the years 1997, 2002 and 2011 and to compare changes in these parameters over time. Sample sizes were moderate, compared to other epidemiological studies, yet they allowed the researchers to obtain an estimation error value close to $\pm 2 \%$. Most importantly, thanks to representative random sampling adopted, it was possible to estimate the value of that error. 


\section{Effectiveness of research fieldwork in NATPOL 2011}

Despite correct sampling, randomness and representativeness may be distorted due to numerous respondent refusals to participate. This can happen since non-random differences may exist between those who agreed to participate and those who did not. Some of these differences may be corrected at the analysis stage (e.g. differences concerning age and gender), whereas others are impossible to detect (e.g. the degree to which someone is interested in their own health). Therefore, low effectiveness at the fieldwork stage may cause a non-random estimation error which is hard to estimate. In the survey described here, the effectiveness rate was $66.5 \%$, which must be considered very high when compared to other surveys carried out at the time in Poland and elsewhere in the world. In the final samples, only older people and female respondents were slightly overrepresented, and that was corrected using weights.

\section{Diagnostic algorithms in accordance with the criteria used in clinical practice}

In the NATPOL study, arterial hypertension was diagnosed on the basis of three BP readings taken during each of two separate visits. Thanks to this, the arterial hypertension diagnostic criteria used in the project remained in compliance with Polish and European clinical practice recommendations [13], which is an approach infrequently used in epidemiological studies. The fieldwork nurses who took the measurements had been thoroughly trained, owing to which the standard procedure was adhered to. The devices used to take BP readings were appropriately certified (BHS, AAMI). Cuffs used in the project were matched in size to the arm circumference of an individual subject, which reduced the possibility of overestimating the prevalence of arterial hypertension among obese respondents. This may be important, since in $20-30 \%$ of people in Poland arm circumference equals $32 \mathrm{~cm}$ or more and, as a result, BP readings taken with the use of a standard-size cuff lead to overestimated results [22].

\section{Future directions and analyses: how the data will/can be used}

Data from NATPOL 2011 Survey will be available to the scientific community for research, as well as to the Ministry of Health, the National Health Fund, the Parliamentary Commission of Health, and to commercial insurance companies. Extensive use of this data by a large number of investigators and institutions will favourably impact public health by providing new insights into disease prevention. The data, especially when compared to that from the NATPOL 2002 Survey, will be very helpful in developing an epidemiological model for the prediction of future changes in mortality caused by coronary heart disease in Poland. This model with the application of IMPACT-PI (7) would also enable the development of alternative action scenarios for the primary and secondary prevention for CVD in Poland and cost-effectiveness analysis of these scenarios. Such a project, in co-operation with the Commission of the European Union (European Heart Health Strategy II - EuroHeart II), is currently being conducted by the Medical University of Gdansk.

\section{Acknowledgements}

We gratefully thank: Prof. Maciej Banach, Prof. Grażyna Broda, Prof. Barbara Cybulska, Dr Marek Guzek, Dr Agata Ignaszewska-Wyrzykowska, Dr Zenon Jakubowski, Dr Hanna Jasiel-Wojculewicz, Mgr Monika Kasprzyk, Prof. Jerzy Korewicki, Dr Stefan Krajnik, Dr hab. Ewa Król, Mgr Ewa Książek-Bator, Prof. Zbigniew Nowicki, Prof. Grzegorz Opolski, Dr Grzegorz Placha, Dr Piotr Popowski, Dr Katarzyna Prusik, Prof. Bolesław Rutkowski, Dr Wojciech Sakłak, Dr Zofia Słońska, Dr Jakub Stokwiszewski, Prof. Krzysztof Sworczak, Prof. Małgorzata Sznitowska, Prof. Wiktor Szostak, Mgr Marta Święch, Dr Łukasz Wierucki, Dr Barbara Wizner, Mgr Elżbieta Wołkiewicz, Dr Małgorzata Wróblewska, Dr Alicja Utracka, Drhab. Paweł Zagożdżon, DrMarzena Zarzeczna-Baran, Dr Łukasz Zdrojewski for their contribution to the success of this study.

This study was partially funded by the Polish Ministry of Health as a publicly-funded project representing part of the National CVD Prevention and Treatment Programme ('Narodowy Program Profilaktyki i Leczenia Chorób Układu Sercowo-Naczyniowego') and by statutory grants from the Medical University of Gdansk and the Medical University in Warsaw. It was also partly funded by the following industry sponsors: the main sponsor of the project: Sanofi-Aventis — unrestricted educational grant; Abbott Laboratories Poland Ltd — sponsor with unrestricted educational grant; Siemens Ltd - partner of the project - unrestricted educational grant; Polpharma - partner of the project — unrestricted educational grant - in the part of the project dedicated to heart failure. The funding agencies had no involvement in the design or conduct of the study; the collection, management, analysis, and interpretation of the data; or the drafting of the manuscript.

Conflict of interest: All authors declare: no support from any organisation for the submitted work; no financial relationships with any organisations that might have had a financial interest in the submitted work in the previous three years; no other relationships or activities that could appear to have influenced the submitted work.

\section{References}

1. Central Statistical Office, Branch Yearbooks, Demographic Year-book of Poland, 2012, Warsaw.

2. Łabęcka M, Kania A, Markowska H. Orzeczenia pierwszorazowe dla celów rentowych wydane w 2006 roku. In: Orzeczenia lekarzy orzeczników ZUS o niezdolności do pracy wydane w 2006 roku. Zakład Ubezpieczeń Społecznych, Warszawa, 2007: 11-32.

3. Zatoński W ed. Closing the health gap in European Union. Cancer Epidemiology and Prevention Division, the Maria Skłodowska-Curie Memorial Cancer Center and Institute of Oncology, 2008. 
4. World Health Organization. European Health for all database (HFA-DB). Geneva: WHO, 2011. Available at: http://data.euro. who.int/hfadb/ [consulted October 2011].

5. Wojtyniak B. In: Poland in Europe - The Demographic Future. Inaugural Session. Edited by Zbigniew Strzelecki, Alina Potrykowska. Rządowa Rada Ludnościowa, Warszawa 2012: 260-266.

6. Wojtyniak B, Goryński P. Sytuacja zdrowotna ludności Polski. Narodowy Instytut Zdrowia Publicznego, Państwowy Zakład Higieny, 2008.

7. Bandosz P, O'Flaherty M, Drygas W et al. Decline in mortality from coronary heart disease in Poland after socioeconomic transformation: modelling study. BMJ, 2012; 344: d8136.

8. Zdrojewski T, Bandosz P, Szpakowski P et al. Rozpowszechnienie głównych czynników ryzyka chorób układu sercowo-naczyniowego w Polsce. Wyniki badania NATPOL PLUS. Kardiol Pol, 2004; 61 (suppl. IV): 546-558.

9. Zdrojewski T, Szpakowski P, Bandosz P et al. Arterial hypertension in Poland in 2002. J Hum Hypertens, 2004; 18: 557-562.

10. Broda G, Rywik S. Multicenter national Polish population health status tests - WOBASZ project with defined problems and treatment goals. Kardiol Pol, 2005; 63 (6 suppl. 4): S601-S604.

11. Capewell S, O'Flaherty M. Rapid mortality falls after risk-factor changes in populations. Lancet, 2011; 378: 752-753.

12. Association for the Advancement of Medical Instrumentation. American national standard. Electronic or automated sphygmomanometers. AAMI, Arlington, VA, 1993.

13. Mancia G, De Backer G, Dominiczak A et al. 2007 Guidelines for the management of arterial hypertension: the task force for the management of arterial hypertension of the European Society of Hypertension (ESH) and of the European Society of Cardiology (ESC). Eur. Heart J, 2007, 28: 1462-536.
14. Krupa-Wojciechowska B, Bandosz P. Prof. dr med. Aleksander Januszkiewicz (1872-1955). Nadciśnienie Tętnicze, 2002; 6: 235-238.

15. Tochowicz L, Król W, Pudlik Z. Górne granice prawidłowych ciśnień tętniczych i częstości nadciśnienia wśród ludności województwa krakowskiego. Pol Arch Med Wewn, 1956; 26: 483-496.

16. Falkiewicz A, Pacyński A, Tarnowski S et al. Nadciśnienie wśród ludności Dolnego Śląska. Pol Tyg Lek, 1962; 17: 281-284.

17. Askanas Z, Czerwińska S, Liszewska D et al. Metoda doboru reprezentatywnej próby do badania rozsiewu ciśnienia tętniczego krwi w dużych populacjach. Pol Tyg Lek, 1965; 23: 830-834.

18. Mikołajczyk W, Czerwińska S, Rywik S et al. Rozkład wartości ciśnienia tętniczego w losowej próbie populacji Płocka zbadanej w 1962 i 1967 r. Przegl Epid, 1970; 24: 527-533.

19. Rywik SL, Davis CE, Pajak A et al. Poland and U.S. collaborative study on cardiovascular epidemiology hypertension in the community: prevalence, awareness, treatment, and control of hypertension in the Pol-MONICA Project and the U.S. Atherosclerosis Risk in Communities Study. Ann Epidemiol, 1998; 8: 3-13.

20. Zdrojewski T, Pieńkowski R, Pająk A et al. Rozpowszechnienie i skuteczność leczenia nadciśnienia tętniczego w Polsce w roku 1997: ocena metodą sondażu reprezentatywnego. Nadciśnienie Tętnicze, 1998; 2 (suppl. 3): 8.

21. Błędowski P, Mossakowska M, Chudek J et al. Medical, psychological and socioeconomic aspects of aging in Poland. Assumptions and objectives of the PolSenior project. Experim Gerontol, 2011; 46: 1003-1009.

22. Bakx C, Oerlemans G, van den Hoogen $\mathrm{H}$ et al. The influence of cuff size on blood pressure measurement. J Hum Hypertens, 1997; 11: 439-445.

\title{
Rozpowszechnienie i kontrola czynników ryzyka sercowo-naczyniowego w Polsce. Cele i sposób realizacji badania NATPOL $2011^{*}$
}

\author{
Tomasz Zdrojewski ${ }^{1}$, Marcin Rutkowski ${ }^{1}$, Piotr Bandosz ${ }^{1}$, Zbigniew Gaciong ${ }^{2}$, Tadeusz Jędrzejczyk ${ }^{3}$, \\ Bogdan Solnica ${ }^{4}$, Michał Pencina ${ }^{5}$, Wojciech Drygas ${ }^{6,7}$, Bogdan Wojtyniak ${ }^{8}$, Tomasz Grodzicki ${ }^{9}$, \\ Jerzy Piwoński ${ }^{6}$, Bogdan Wyrzykowski ${ }^{1}$ \\ 'Katedra Nadciśnienia Tętniczego i Diabetologii, Gdański Uniwersytet Medyczny, Gdańsk \\ ${ }^{2}$ Katedra Chorób Wewnętrznych, Nadciśnienia Tętniczego i Angiologii, Warszawski Uniwersytet Medyczny, Warszawa \\ ${ }^{3} Z a k ł a d$ Zdrowia Publicznego i Medycyny Społecznej, Gdański Uniwersytet Medyczny, Gdańsk \\ ${ }^{4}$ Zakład Diagnostyki Katedry Biochemii Klinicznej, Collegium Medicum, Uniwersytet Jagielloński, Kraków \\ ${ }^{5}$ Katedra Biostatystyki, Boston University, Boston, Stany Zjednoczone \\ ${ }^{6}$ Zakład Epidemiologii, Prewencji Chorób Układu Krążenia i Promocji Zdrowia, Instytut Kardiologii, Warszawa \\ ${ }^{7}$ Katedra Medycyny Społecznej i Zapobiegawczej, Uniwersytet Medyczny w Łodzi, Łódź \\ ${ }^{8}$ Narodowy Instytut Zdrowia Publicznego — Państwowy Zakład Higieny, Warszawa \\ ${ }^{9}$ Katedra Chorób Wewnętrznych i Gerontologii, Collegium Medicum, Uniwersytet Jagielloński, Kraków
}

*Akronim badania NATPOL: Nadciśnienie tętnicze oraz inne czynniki ryzyka chorób serca i naczyń w Polsce 


\section{Streszczenie}

Wstęp: Choroby układu sercowo-naczyniowego (CVD) są główną przyczyną przedwczesnej umieralności w Polsce. Od 1991 r. umieralność spowodowana tymi schorzeniami w naszym kraju systematycznie maleje, jednak nadal pozostaje jedną z największych w Europie. Analiza wykonana z użyciem modelu epidemiologicznego IMPACT i danych pochodzących z badań przekrojowych prowadzonych w latach 1991-2005 wykazała, że umieralność spowodowana chorobą niedokrwienną serca w ostatnim 20-leciu zmniejszyła się głównie dzięki zmianom stylu życia Polaków (54\% obserwowanej redukcji umieralności). Rozwój medycyny naprawczej także przyczynił się do redukcji liczby zgonów, choć w nieco mniejszym stopniu (37\%). Dlatego bardzo istotna z punktu widzenia planowania polityki zdrowotnej państwa jest wiedza o rozpowszechnieniu zależnych od stylu życia czynników ryzyka CVD. Jeszcze ważniejsze są informacje o zmianach obciążenia populacji czynnikami ryzyka. Pozwoli to przewidywać przyszłe trendy umieralności, a także korzyści płynące z różnorodnych strategii populacyjnych w zakresie profilaktyki CVD. Ostatnie badanie przekrojowe dotyczące rozpowszechnienia czynników ryzyka CVD w populacji ogólnopolskiej przeprowadzono w latach 2005-2007, natomiast w 2011 r. zrealizowano badanie NATPOL 2011 będące najnowszym tego typu przedsięwzięciem w Polsce.

Cel: Celem badania NATPOL 2011 była ocena rozpowszechnienia wybranych czynników ryzyka CVD, w tym nadciśnienia tętniczego, zaburzeń lipidowych i cukrzycy w Polsce na podstawie badania reprezentatywnej próby mieszkańców oraz określenie aktualnych trendów w tym zakresie. Przedmiotem niniejszej publikacji jest natomiast szczegółowe określenie metodologii badania.

Metody: Projekt NATPOL 2011 zaplanowano jako badanie metodą reprezentacyjną. Grupę badaną stanowiła reprezentatywna dla populacji ogólnopolskiej próba 2413 dorosłych osób (zakres wieku 18-79 lat). W celu uzyskania próby zastosowano losowanie warstwowe z uwagi na miejsce zamieszkania, wiek i płeć. Próba była skupiona w wiązkach terytorialnych. Dobór próby był etapowy: I etap — losowanie gmin, II etap — losowanie wiązek w obrębie gmin i losowanie indywidualnych respondentów (wykonane przez MSWiA z operatu PESEL). U każdego badanego, który wyraził na to zgodę, przeprowadzono badanie kwestionariuszowe, pomiary ciśnienia tętniczego (3 pomiary podczas dwóch oddzielnych wizyt), pomiary antropometryczne. Pobrano także próbki krwi i moczu w celu wykonania oznaczeń biochemicznych [cholesterol całkowity w surowicy krwi; cholesterol frakcji LDL (wyliczony), HDL w surowicy krwi; triglicerydy na czczo w surowicy krwi; glukoza na czczo w osoczu krwi; sód i potas w surowicy krwi; kreatynina w surowicy krwi; insulina na czczo w surowicy krwi; białko C-reaktywne w surowicy krwi; aminotransferazy alaninowa i asparaginianowa w surowicy krwi; bilirubina w surowicy krwi; albumina w surowicy krwi; TSH, fT4 w surowicy krwi; albumina w moczu; kreatynina w moczu; sód i potas w moczu; NT-proBNP w osoczu]. Prace terenowe były realizowane przez specjalnie przeszkolone pielęgniarki zamieszkujące w pobliżu wylosowanych wiązek terytorialnych. Głównym realizatorem badania był zespół Kliniki Nadciśnienia Tętniczego i Diabetologii Uniwersyteckiego Centrum Klinicznego w Gdańsku. Badanie zrealizowano we współpracy z Warszawskim Uniwersytetem Medycznym i Instytutem Kardiologii w Warszawie.

Wyniki i wnioski: Listy zapraszające wysłano do 4420 potencjalnych uczestników badania. Spośród nich 786 osób było niedostępnych z powodu błędnego adresu, zmiany miejsca zamieszkania lub zgonu przed rozpoczęciem badania. Kolejne 661 osób bądź odmówiło udziału w badaniu, bądź pielęgniarkom nie udało się z nimi nawiązać kontaktu. Ostatecznie w badaniu wzięło udział 2413 osób, natomiast pełen zestaw badań, w tym próbki krwi i moczu, uzyskano w 2401 przypadkach, dlatego efektywność badania wyniosła 66,5\%. Struktura próby zbadanej pod względem wieku i płci była niemal identyczna ze strukturą populacji polskiej z 2010 r. według GUS. Zakres nadanych wag wyniósł: 0,36-4,11.

Słowa kluczowe: choroby sercowo-naczyniowe, czynniki ryzyka, rozpowszechnienie

Kardiol Pol 2013; 71, 4: 381-392 
SUPPLEMENT 1. Tests performed in Central Clinical Laboratory — NATPOL 2011

\begin{tabular}{|c|c|c|c|c|c|c|}
\hline & \multirow[b]{2}{*}{ Test } & \multirow[b]{2}{*}{$\begin{array}{l}\text { Methodology/reagents } \\
\text { manufacturer }\end{array}$} & \multirow[b]{2}{*}{ Analyser } & \multicolumn{3}{|c|}{$\begin{array}{l}\text { Analytical characteristics } \\
\text { of the method applied }\end{array}$} \\
\hline & & & & $\frac{\mathscr{c}}{0}$ & 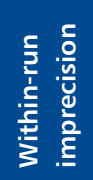 & 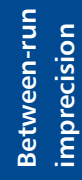 \\
\hline 1 & $\begin{array}{l}\text { Serum } \\
\text { cholesterol }\end{array}$ & $\begin{array}{l}\text { Enzymatic/cholesterol esterase and cholesterol } \\
\text { oxidase/Abbott Laboratories }\end{array}$ & $\begin{array}{l}\text { Architect c8000 Abbott } \\
\text { Laboratories }\end{array}$ & $-1.00 \%$ & $0.60 \%$ & $1.50 \%$ \\
\hline 2 & $\begin{array}{l}\text { Serum } \\
\text { HDL-cholesterol }\end{array}$ & $\begin{array}{l}\text { Direct method - Accelerator Selective } \\
\text { Detergent (ASD) with accelerated } \\
\text { non-HDL-C oxidation and HDL-C dissolving/ } \\
\text { /Abbott Laboratories }\end{array}$ & $\begin{array}{l}\text { Architect c8000 Abbott } \\
\text { Laboratories }\end{array}$ & $2.00 \%$ & $1.10 \%$ & $5.70 \%$ \\
\hline 3 & $\begin{array}{l}\text { LDL-cholesterol } \\
\text { — calculated }\end{array}$ & $\begin{array}{l}\text { Using Friedewald formula: } \\
\mathrm{LDL}-\mathrm{C}[\mathrm{mg} / \mathrm{dL}]=\text { total cholesterol }[\mathrm{mg} / \mathrm{dL}]-\mathrm{HDL}-\mathrm{C} \\
\text { If triglycerides concentration }>350 \mathrm{mg} / \mathrm{dL} \text {, Friede }\end{array}$ & $\begin{array}{l}{[\mathrm{mg} / \mathrm{dL}] \text { - triglycerides }[\mathrm{mg} / \mathrm{dL}] / 5} \\
\text { vald formula cannot be used }\end{array}$ & & & \\
\hline 4 & Serum triglycerides & $\begin{array}{l}\text { Enzymatic/glycerol kinase and glycerol } \\
\text { phosphate oxidase/Abbott Laboratories }\end{array}$ & $\begin{array}{l}\text { Architect c } 8000 \text { Abbott } \\
\text { Laboratories }\end{array}$ & $1.35 \%$ & $1.43 \%$ & $1.44 \%$ \\
\hline 5 & Plasma glucose & $\begin{array}{l}\text { Enzymatic/hexokinase and glucose-6-phosphate } \\
\text { dehydrogenase/Abbott Laboratories }\end{array}$ & $\begin{array}{l}\text { Architect c8000 Abbott } \\
\text { Laboratories }\end{array}$ & $-2.70 \%$ & $1.30 \%$ & $2.10 \%$ \\
\hline 6 & Serum sodium & $\begin{array}{l}\text { Indirect ion-selective electrode/Abbott } \\
\text { Laboratories }\end{array}$ & $\begin{array}{l}\text { Architect c8000 Abbott } \\
\text { Laboratories }\end{array}$ & $-0.82 \%$ & $0.35 \%$ & $1.45 \%$ \\
\hline 7 & Urine sodium & $\begin{array}{l}\text { Indirect ion-selective electrode/Abbott } \\
\text { Laboratories }\end{array}$ & $\begin{array}{l}\text { Architect c8000 Abbott } \\
\text { Laboratories }\end{array}$ & $2.36 \%$ & $0.51 \%$ & $1.46 \%$ \\
\hline 8 & Serum potassium & $\begin{array}{l}\text { Indirect ion-selective electrode/Abbott } \\
\text { Laboratories }\end{array}$ & $\begin{array}{l}\text { Architect c } 8000 \text { Abbott } \\
\text { Laboratories }\end{array}$ & $0.80 \%$ & $0.30 \%$ & $1.50 \%$ \\
\hline 9 & Urine potassium & $\begin{array}{l}\text { Indirect ion-selective electrode/Abbott } \\
\text { Laboratories }\end{array}$ & $\begin{array}{l}\text { Architect c8000 Abbott } \\
\text { Laboratories }\end{array}$ & $0.80 \%$ & $0.40 \%$ & $1.30 \%$ \\
\hline 10 & Serum creatinine & $\begin{array}{l}\text { Jaffe method: the reaction with picrate in } \\
\text { alkaline milieu/Abbott Laboratories }\end{array}$ & $\begin{array}{l}\text { Architect c } 8000 \text { Abbott } \\
\text { Laboratories }\end{array}$ & $1.10 \%$ & $1.30 \%$ & $3.10 \%$ \\
\hline 11 & eGFR & $\begin{array}{l}\text { Calculated using the simplified MDRD equation: } \\
\text { where: } S-\text { serum creatinine }[\mu \mathrm{mol} / \mathrm{L}] ; Z=0.742\end{array}$ & $\begin{array}{l}F F R=175 \times\left[(S \times 0.0113)^{-1.154}\right] \times \\
\text { factor for females); } Z=1(\text { factor }\end{array}$ & $\begin{array}{l}x \text { [age (years } \\
\text { for males) }\end{array}$ & $203 \times Z$ & \\
\hline 12 & Urine creatinine & $\begin{array}{l}\text { Jaffe method: the reaction with picrate } \\
\text { in alkaline milieu/Abbott Laboratories }\end{array}$ & $\begin{array}{l}\text { Architect c } 8000 \text { Abbott } \\
\text { Laboratories }\end{array}$ & $5.40 \%$ & $1.50 \%$ & $2.50 \%$ \\
\hline 13 & Serum insulin & Immunochemiluminescence/Abbott Laboratories & $\begin{array}{l}\text { Architect } 12000 \text { Abbott } \\
\text { Laboratories }\end{array}$ & $2.30 \%$ & $1.50 \%$ & $3.30 \%$ \\
\hline 14 & Serum CRP & Immunoturbidimetry/Abbott Laboratories & $\begin{array}{l}\text { Architect c8000 Abbott } \\
\text { Laboratories }\end{array}$ & $8.90 \%$ & $1.74 \%$ & $2.55 \%$ \\
\hline 15 & Serum total bilirubin & Diazonium salt/Abbott Laboratories & $\begin{array}{l}\text { Architect c8000 Abbott } \\
\text { Laboratories }\end{array}$ & $-10.90 \%$ & $2.70 \%$ & $6.40 \%$ \\
\hline 16 & Serum AST & $\begin{array}{l}\text { NADH without pyridoxal phosphate/ } \\
\text { /Abbott Laboratories }\end{array}$ & $\begin{array}{l}\text { Architect c8000 Abbott } \\
\text { Laboratories }\end{array}$ & $-8.80 \%$ & $0.90 \%$ & $1.00 \%$ \\
\hline 17 & Serum ALT & $\begin{array}{l}\text { NADH without pyridoxal phosphate/ } \\
\text { /Abbott Laboratories }\end{array}$ & $\begin{array}{l}\text { Architect c8000 Abbott } \\
\text { Laboratories }\end{array}$ & $-0.60 \%$ & $1.40 \%$ & $1.70 \%$ \\
\hline 18 & Serum albumin & Bromocresol purple/Abbott Laboratories & $\begin{array}{l}\text { Architect c8000 Abbott } \\
\text { Laboratories }\end{array}$ & $-0.60 \%$ & $1.40 \%$ & 1.75 \\
\hline 19 & Serum TSH & Immunochemiluminescence/Abbott Laboratories & $\begin{array}{l}\text { Architect } 12000 \text { Abbott } \\
\text { Laboratories }\end{array}$ & $2.79 \%$ & $2.01 \%$ & $2.82 \%$ \\
\hline 20 & Serum ft4 & Immunochemiluminescence/Abbott Laboratories & $\begin{array}{l}\text { Architect } 12000 \text { Abbott } \\
\text { Laboratories }\end{array}$ & $-4.95 \%$ & $6.04 \%$ & $8.34 \%$ \\
\hline 21 & Urine albumin & Immunoturbidimetry/Abbott Laboratories & $\begin{array}{l}\text { Architect c } 8000 \text { Abbott } \\
\text { Laboratories }\end{array}$ & $3.72 \%$ & $4.45 \%$ & $5.28 \%$ \\
\hline 22 & Plasma NT-proBNP & $\begin{array}{l}\text { Immunochemiluminescence/Siemens } \\
\text { Healthcare Diagnostics }\end{array}$ & $\begin{array}{l}\text { Immulite } 1000 \text { Siemens } \\
\text { Healthcare Diagnostics }\end{array}$ & $-7.96 \%$ & $0.15 \%$ & $0.35 \%$ \\
\hline 23 & Serum apoA1 & $\begin{array}{l}\text { Immunonephelometry/Siemens } \\
\text { Healthcare Diagnostics }\end{array}$ & $\begin{array}{l}\text { BN II Siemens } \\
\text { Healthcare Diagnostics }\end{array}$ & $5.13 \%$ & $1.81 \%$ & $7.97 \%$ \\
\hline 24 & Serum apoB & $\begin{array}{l}\text { Immunonephelometry/Siemens } \\
\text { Healthcare Diagnostics }\end{array}$ & $\begin{array}{l}\text { BN II Siemens } \\
\text { Healthcare Diagnostics }\end{array}$ & $-4.66 \%$ & $3.94 \%$ & $9.38 \%$ \\
\hline
\end{tabular}

